Whittle A, Mueller F. 'I could be dead for two weeks and my boss would never know': Telework and the politics of representation. New Technology, Work and Employment 2009, 24(2), 131-143.

\title{
Copyright:
}

This is the peer reviewed version of the following article: Whittle A, Mueller F. 'I could be dead for two weeks and my boss would never know': Telework and the politics of representation. New Technology, Work and Employment 2009, 24(2), 131-143, which has been published in final form at http://dx.doi.org/10.1111/j.1468-005X.2009.00224.x. This article may be used for non-commercial purposes in accordance With Wiley Terms and Conditions for self-archiving'.

DOI link to article:

http://dx.doi.org/10.1111/j.1468-005X.2009.00224.x

Date deposited:

$12 / 05 / 2015$

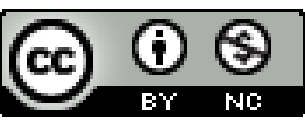

This work is licensed under a Creative Commons Attribution-NonCommercial 3.0 Unported License 
This is the author(s) personal version of the manuscript, as accepted after the review process but prior to final layout and copyediting by the publisher. The final version is published as:

Whittle, A. \& Mueller, F. (2009) 'I could be dead for two weeks and my boss would never know': Telework and the politics of representation. New Technology, Work and Employment. 24(2): 131-143.

Readers are kindly asked to use the official publication in references.

\title{
"I could be dead for two weeks and my boss would never know":
}

\section{Telework and the politics of representation}

\begin{abstract}
This article presents data from a qualitative study of teleworking consultants in a European firm. We examine the 'gap' between the utopian visions produced by the consultants for the benefit of clients and the tales of isolation, dis-connection, disaffection and cynicism we observed when clients were not present. The study highlights the power and politics involved in the diffusion of popular images of technology-enabled flexibility.
\end{abstract}

Keywords: Flexibility, Management Consulting, Politics, Telecommuting, Telework. 
The term 'flexibility' has been used to refer to a plethora of different organizational changes, from post-Fordist flexible specialisation (Vallas, 1999), new forms of numerical, functional, financial and distancing flexibility as outlined in the ‘core/periphery’ model (Atkinson, 1984; Capelli \& Neumark, 2004), to the rise of 'virtual' organizations boasting new forms of technology-enabled temporal and spatial flexibility (Jackson, 1999) - the focus of this article. In this article we examine how a group of flexible working consultants enacted a politics of representation that strategically hid and deleted particular aspects of their 'back-stage' work from the 'front-stage' performance (Goffman, 1959) given to clients. The term 'front-stage' refers to the performance given in public (i.e. to clients), compared to the 'back-stage' interactions that take place in 'private' (i.e. with clients not present). This 'politics of representation', we suggest, enabled visions of flexibility to be reproduced in ways that furthered the interests of firms such as our case study Alpha, who sought to benefit from presenting technology as a neutral and efficient medium for achieving flexibility.

The article is structured as follows. First we review the various ways in which flexibility has been conceptualised, paying particular attention to the more critical literature that has questioned the idea that flexibility represents a neutral source of efficiency. Following a short overview of the methodology employed in the study, we move on to examine data from a fieldwork observation of a sales pitch delivered by one of the consultants to potential clients. This is then contrasted with data from the 'back-stage' actions and interactions we observed when the consultants were not client-facing. We highlight the 'hidden' labour involved in flexible working and the voices 'deleted' from the front-stage performance (cf Schwartz, Nardi and Whittaker, 1999). We conclude by arguing that the heady visions of technology-enabled flexible 
work produced by the consultants involve a 'politics of representation', where certain (utopian) narratives are voiced and other (more critical) voices are silenced or sidelined. In spite of the cynicism and ambivalence created by the gap between the front-stage and back-stage performances, the consultants remained complicit in the reproduction of these power relations. This, we conclude, enabled the representation of flexibility preferred by their employers, Alpha, to appear as a 'neutral' and 'natural' outcome of technological change, as opposed to political and power-laden, with consequences for those who encountered it.

\section{Flexibility: Competing Perspectives}

The term flexibility can be traced back to Atkinson's 'core-periphery model' of the firm (Atkinson, 1984; Osterman, 1988, p. 69), which mapped the shift towards restructuring the workforce to be more adaptive to changes in their environment and transfer risk away from the firm. Atkinson's model described four types of flexibility, including forms of functional flexibility associated with multi-skilling and job rotation (Mueller, 1992) and the allocation of additional responsibilities to production employees (Sels \& Huys, 1999), numerical flexibility associated with the use of nonstandard employment conditions such as temporary contracts (Capelli \& Neumark, 2004), financial flexibility associated with individualised non-unionised payment systems (Heery, 1997) and distancing flexibility associated with the use of subcontractors, agency workers and freelance workers (Baines, 1999; Kalleberg, 2001). The search for more agile and responsive 'post-bureaucratic' organizational forms has also led to the popularity of business process reengineering, downsizing and delayering initiatives (Kanter, 1985; Peters, 1992), post-Fordist flexible specialisation (Vallas, 1999), various forms of teamwork (Mueller, 1994) and project-based 
organizations (Hodgson, 2004). More recently, changes in Information and Communication Technology (ICT) have enabled firms to pursue new forms of temporal and spatial flexibility, including home-based and nomadic working practices (Bone, 2006; Sullivan, 2003; Jackson, 1999; Tietze \& Musson, 2005), virtual and distributed teams (Maznevski \& Chudoba, 2000; Pyöriä, 2003) and the off-shoring of entire business functions, typified by the use of overseas call centres (Poster, 2007). However, it must be noted that the 'flexible firm' may be more of a myth than a reality, given its limited uptake and the many continuities in the labour market (Pollert, 1991). The use of new flexible post-bureaucratic structures may also be somewhat exaggerated, given the endurance of bureaucratic organizational forms (Bolin \& Harenstam, 2008).

The focus of this paper is on technology-enabled flexible working practices, such as working from home or 'on the road', often referred to as 'tele-work', 'virtual work’ or ‘e-work’ (Jackson, 1999; Hardill \& Green, 2003), or more recently ‘homeanchored work’ (Wilks \& Billsberry, 2007; Bone, 2006) ${ }^{1}$. Advances in ICT have been accompanied by utopian visions and heady predictions of the benefits of using technology to break down the barriers of time and space (Baines, 1999). While this 'cyber-bole' (Woolgar, 2002) is widespread, it is not 'new' as such. In the 1970s, Nilles (1976) predicted a revolution in the organization of work enabled by new technology, with visions of idyllic countryside tele-cottages that would regenerate communities and enhance family life. In these new 'virtual' organizations, it is suggested, instantaneous information exchange makes it possible for work to be conducted anywhere and anytime (Jackson, 1999).

More critical commentators, however, have sought to expose the power relations underlying popular images of flexibility. The key question for critical commentators 
is ‘flexibility for whom?’ (Furåker, Håkansson \& Karlsson, 2007). Dawson and Webb (1989) warned against the view that modern production arrangements would signal the general enhancement of working life. Indeed, Legge (1995) exposes the degradation of employment conditions associated with the core-periphery model of the firm. Similarly, Sennett's (2006) critique of new 'flexible capitalism' highlights the high levels of stress and anxiety (p. 52) created by the trends towards casualisation and delayering of the workforce (p. 49) (see also Baines, 1999). New forms of surveillance, work intensification, stress and insecurity have been uncovered amongst the apparently 'empowered' workers and self-managing teams of the so-called postFordist workplace (Sewell, 1998; Thompson \& Warhurst, 1998; Bain \& Taylor, 2000; Dawson \& Webb, 1989; Voudouris, 2007: 241). Flexible employment practices have been found to generate economic uncertainty, isolation, job insecurity, gender inequality, reduced career prospects, longer working hours and work/life imbalance amongst the workforce (Allan, Brosnan \& Walsh, 1998; Heiler, 1998; Chirumbolo \& Hellgren, 2003, Smithson et al 2004; Bone, 2006).

Research on telework and home-based work has also questioned the idyllic visions of freedom to work anywhere and anytime, helping to balance the demands of work and family life. More critical work has highlighted the reproduction of gender inequalities (Bryant, 2000), including the gender pay gap (Smithson et al. 2004), especially where predominantly female, low paid clerical and customer service work is affected (Huws, 1996). Teleworkers have reported feeling stressed, controlled, lonely, insecure, isolated and exploited (Stanworth \& Stanworth, 1991; Baines, 1999; Bertin and Denbigh, 2000; Baruch, 2000; Dimitrova, 2003; Mann \& Holdsworth, 2003; Taskin \& Edwards, 2007), albeit experiences not exclusive to teleworkers. Families have also faced major challenges as 'work' comes 'home' (Mirchandani, 
1999; Baruch, 2000; Tietze \& Musson, 2005), demanding a re-negotiation of domestic responsibilities to accommodate work obligations (Hyman, Scholarios \& Baldry, 2005). Even for the 'winners' of telework arrangements, financial rewards can come at a heavy price (Bone, 2006) as work encroaches on the personal lives of workers (Peper, Den Dulk \& Van Doorne-Huiskes, 2005), making home-based work far from ‘family friendly’ (Baines \& Gelder, 2003).

Existing literature, as we have reviewed above, has tended to focus on the impact of flexible working practices on the workforce. To date, little attention has been paid to how visions of flexibility are constructed, devised and implemented. Our contribution is to explore the politics involved in how visions of technology-enabled flexible work are created and sustained. The story presented in this article is crafted by comparing and contrasting the 'front-stage' (Goffman, 1959) performances performed by a group of flexible working consultants to their (existing or prospective) client audience and the 'back-stage' performances to which clients were not privy. A short discussion of the work of Erving Goffman (1959; 1972; 1974) is therefore relevant here. Goffman's work has inspired a substantial body of literature in management and organization studies, including work on the dramaturgical metaphor, impression management, interactional rituals, identity and 'face-work' and organizational symbolism in general (see eg. Mangham and Overington, 1987; Rosenfeld, Giacalone and Riordan, 1995; Gardner and Avolio, 1998). Goffman distinguished between the front-stage - where actors are 'on stage' and attempt to 'pull off' a polished version of their performance, control the responses of the audience and create favourable impressions - in contrast with the back-stage activities that occur 'behind the scenes'. However, the term 'front-stage' is not intended to suggest that it is somehow more (or less) 'real' than the 'back-stage' (Goffman, 1959, 
p. 72). Rather, they can be understood as different ways of 'framing' the situation (Goffman, 1974), that is, providing different ways of defining the situation, i.e. 'what is going on here?' and 'what sort of behaviour is expected?' For instance, the consultants in our study understandably 'framed' flexible working differently in front of clients - who they had to 'sell' the idea to - compared to how they 'framed' their experience when speaking to the researcher.

The dramaturgical approach, which views life as a stage upon which people perform and construct impressions of the self, as already proven itself as a fruitful avenue for understanding the work of management consultants (Clark, 1995; Clark and Salaman, 1998; Clark and Mangham, 2004). Whilst the focus of existing literature on the 'front-stage' performances of consultants is understandable - after all, this is where client impressions tend to be created - this focus has nevertheless left our understanding of the back-stage life of management consultants under-developed. Where the back-stage has been investigated, it has been conceptualised as a place for 'rehearsal' and preparation for the front-stage performance (eg. Clark and Mangham, 2004). Here the back-stage is assumed to be consistent with (and leading to) the frontstage performance, albeit in a more ‘unpolished' format.

This article aims to further our understanding in three ways. First we depart from this 'rehearsal' approach by highlighting the contradictions, tensions and inconsistencies between the front-stage and back-stage performances of flexibility we uncovered. Second, we seek to highlight the links between the micro-sociological analysis of interaction inspired by Goffman and the broader social, economic and political interests that mundane day-to-day interactions serve to reproduce or challenge. Third and finally, as Star and Strauss (1999) argue, going back-stage is important for revealing the politics behind 'hidden' work, such as the gender 
dynamics of domestic labour (see also Huws, 1996; Mirchandani, 1999; Bryant, 2000). Accordingly, we argue that the invisibility of back-stage work can also act as a political tool, in this case to obscure the corporate interests it embodies.

\section{The Study}

FlexiTeam were a team of ten management consultants employed by a large technology-sector firm called ‘Alpha’ (a pseudonym). FlexiTeam represent a critical case for studying teleworking because they were at the forefront of diffusing visions of technology-enabled flexibility. The consultant not only implemented flexible working in client firms but also sought to influence the wider debate about flexibility and advance their own preferred version of what flexibility 'means' through conference speeches, brochures, road-shows, exhibitions and articles in trade journals, magazines, websites and newspapers. These activities are important because they attempt to define what flexible working 'is' and can 'do', and hence how it is enacted.

The ethnographic study consisted of non-participant observation and semistructured interviews over a period of around nine months between 2000 and 2001, followed by several follow-up visits in 2002 and 2003. The researcher (one of the authors of this paper) sought to participate in all aspects of the consultants' daily working lives. This included attending client visits, home office visits, team meetings, performance review meetings and numerous social activities, as well as semistructured interviews. In addition, the methodology was adapted to the often 'virtual' nature of their work as a distributed 'virtual' team of home-based flexible workers by collecting email conversations posted to the group discussion list and tape-recording the weekly audio-conference discussions. Access was not granted, however, to observe individual emails or phone-calls, for obvious reasons of personal privacy. 
Data was recorded using a mixture of tape-recording (for interviews, audioconferences and certain meetings where permission was granted), documents (in paper or electronic form) and field-notes written either during or shortly after the event. The data was analysed by first transcribing the various sources, then coding the data into common or contrasting themes. In qualitative studies such as this, themes cannot be defined a priori and then simply applied to the data to enable 'results' to 'fall out' (Bryman and Burgess, 1994). Indeed, the analyst can never be sure to have organized the data in a definitive way, or that another analyst would have collected and analysed the data differently (Bryman, 1989; Silverman, 1993). Like other studies of this nature (eg. Okely, 1994; Hughes, 1994), the conceptual ideas that developed into this article were made after the fieldwork was completed. They were based on a movement between our understanding of the 'emic' (i.e. the world-view of the participants) and the 'etic' (i.e. academic theories and concepts) (Hammersley and Atkinson, 1995). As such, the study was never 'theory free' in the sense that decisions about data collection and analysis were founded upon having adopted "either tacitly or explicitly, certain ways of seeing” (Silverman, 1993, p. 46). Therefore, the data could have been interpreted in different ways by other researchers or by following a different theoretical approach.

The analysis was conducted as follows. First, during the process of re-reading the data (including interview, documents, observations, emails and audioconferences), a discontinuity was spotted between the claims about flexible working made to clients (eg. in their brochures, presentations, 'sales pitches' etc.) and the practices and conversations we observed when clients were not present (eg. during lunch-breaks, team meetings etc.). For example, we noticed a marked contrast between the claims made about a database enabling seamless data transfer made to a 
prospective client and observations of the difficulties the consultants were facing in using this database. Next we searched the entire data-set for other instances of contradiction and copied these into a separate file. The data presented in this article is thus a selective sample of the data collected during the study. This is common practice for ethnographic methodology and qualitative social science more generally, where large data-sets cannot be reproduced in their entirety (Hollway and Jefferson, 2000). For instance, this study produced four books of field-notes, over one hundred emails, numerous electronic and paper documents and more than sixty hours of tape-recorded interviews and audio-conferences. As Silverman (1993, p. 39) reminds us, the skill is not to accumulate as much data as you can, but to 'can' (get rid of) most of the data you accumulate. Hence, the aim is to offers the reader a necessarily selective, partial and situated 'tale from the field' (van Maanen, 1988) that attempts to relate the ethnographer's experience of life with the 'natives'. As Geertz (1988) observed, the point is not simply to recount a series of disembodied facts but offer the reader a sense of 'being there'.

\section{Utopian Visions: The Front-Stage Performance}

Gaining access to the consultants' interactions with the clients was one of the most difficult tasks faced during the fieldwork. This was understandable given the sensitivity and significance of these interactions. We were particularly pleased, then, when consultant Barry invited the researcher to join him on a visit to a prospective client. Barry was meeting two managers of a prospective client in an advertising company, Steve and Claire. Barry explained that he had been invited to have a preliminary discussion about the possibility of enlisting FlexiTeam to help implement flexible working in the company. 
The following extract is based on the field-notes written during the meeting ${ }^{2}$. The extract has been chosen because it illustrates the sorts of claims about flexible working made during these front-stage performances. For the purposes of this paper, three aspects of the performance are particularly relevant. First, Barry seemed keen to highlight the potential of technology for solving the 'problem' of knowledge sharing ("We have a database that you can access from anywhere"). Second, Barry emphasised the importance of maintaining teamwork ("we make sure we meet up every month for a team meeting”). Third and finally, Barry made claims about the work-life balance benefits of flexible working ("I'd be mowing my lawn at lunchtime”). These claims, we suggest, are not surprising given the need to present flexible working as an easy, seamless solution to the client's problems.

Steve: The reason why we've invited you here today is we've been forced to think seriously about it [flexible work] recently. There's a sort of carrot and a stick going on I suppose. There's the government legislation [right to request to work flexibly] coming up as we all know ... but we also have a workforce of mainly women, and the commute is quite long for most of them, and we want to be able to keep people when they have kids.

Claire: But we aren't totally sure about the whole thing though. I mean, it would be a big change. And we are a very creative company - it's the industry we're in - and we need our staff to work together. Like the amount of ideas that come up when people bump into each other in the kitchen here. We do a lot of spontaneous brainstorming. People rush into my office to ask me things. We don't want all the knowledge to be lost, people to take it home. We want them to work as a team. So, I don't know, maybe if we did do it we could limit it to no more than three days a week at home?

Barry: Absolutely, I mean you're right to be concerned but really there's no barrier. There's no blocker. There's ways around everything. Like, in 
our team, we have processes for all of that... We have a database that you can access from anywhere, where you can upload information, to keep that knowledge sharing going. I think we've disproved the myth that if people don't see each other every day they don't collaborate.... That's not to say that face-to-face contact isn't important, in fact it's more important than ever. ... So we make sure we meet up every month for a team meeting. But we also have audiocalls every week and we email a lot too. ... But it's not right for everyone, so what we did in Alpha was do the whole thing on a voluntary basis. You can't force people to work from home. But for those who, like you said about kids, for them it's great. I mean, when I'm not with clients I'd be mowing my lawn at lunchtime [looks at watch], about now in fact! [laughter]

Steve: Wow! [laughs] That does sound better than being here! [laughter]

In our analysis we will focus on the claims made by Barry about the use of technology to enable knowledge transfer in virtual teams and the importance of maintaining teamwork with dispersed, home-based employees.

\section{Technology and Knowledge Sharing: A Back-stage Performance}

During his 'sales pitch' presented above, Barry highlighted the way in which technology enabled his team to share knowledge while separated in time and space. We immediately recognised this as a reference to the database system we had already been shown called 'ClientInfo'. ClientInfo was used to share information about prospective clients (for knowledge sharing purposes) and track client projects (also for billing purposes). The database was supposed to support flexible workers and 'virtual teams’ like FlexiTeam, who could update it from anywhere, anytime using an Internet connection. However, at the time of my study, FlexiTeam seemed to constantly struggle to achieve this vision of seamless connection. Practical problems surrounding how to connect to the database were a constant source of frustration. 
Here we will pay particular attention to the discussion at one team meeting. The extract was chosen because it reveals a story very different to the one presented by Barry to clients. The discussion at the team meeting started with Georgina, the consultant in charge of ensuring the database was kept up to date:

Nigel: Business development manager (chairperson)

Georgina: Consultant

Eric: Team leader

Carol: E-marketing/consultant

Terry: Consultant/business development manager

Barry: Consultant/business development manager

Kevin: Consultant

?: Unable to identify voice

1 Nigel: ClientInfo database. Georgina said don't touch it until she's emailed the team to say it's safe.

2 Kevin: When I was at the Birmingham Office I made sure that one of the things I do when I'm in the building is to access the ClientInfo database.

3 Eric: $\quad$ But it means coming to a building.

4 Terry: It's a pain, cos you have to be on a network.

5 Terry: A pragmatic way if we were stuck, I know it's not ideal and it goes against the way we opened them, we could literally send round a voicemail saying can someone online mail me a copy of the database, you'd get it in 10 minutes. I know you couldn't send me one at 10 o'clock at night, but if you had an inkling at 5 o'clock.

6 Georgina: I wouldn't dwell on this anymore

7 Eric: It's great, I mean, in terms of having one place where you can update your ClientInfo, your timesheet, give you a list of accounts, 


\begin{tabular}{|c|c|c|}
\hline 8 & Terry: & It's just getting access to it! \\
\hline 9 & Martin: & It is quite good actually. \\
\hline 10 & Terry: & But you could open it anyway and work on it on the G drive? \\
\hline 11 & Eric: & $\begin{array}{l}\text { I can, I just need to go into a building. ... There was no reason for } \\
\text { me to get onto a LAN ever, until now! [laughter] }\end{array}$ \\
\hline .... & & \\
\hline 12 & Martin: & $\begin{array}{l}\text { The short term solution, if you want to see it, just get someone } \\
\text { online to send you a copy of it, and you'll get it in an email and } \\
\text { you'll have the latest copy. }\end{array}$ \\
\hline 13 & Terry: & $\begin{array}{l}\text { And once a week post a copy on the shared folders for those that } \\
\text { need access and then synchronise. }\end{array}$ \\
\hline 14 & Nigel: & We all know we need to do that? Is everyone happy with that? \\
\hline 15 & ? & Yep. \\
\hline 16 & Nigel: & Right, next item then ... \\
\hline
\end{tabular}

Two key aspects of this back-stage discussion are relevant for this paper. The first concerns the labour involved in using the ClientInfo database. This discussion took up over half an hour of the team meeting (sections of the transcript have been edited out [marked ...] for brevity). In fact, the issue was still not resolved months later. Following several troubleshooting meetings and calls to the help-desk, some members remained 'disconnected'. This mundane experience of 'technology-work' (Schwartz, Nardi and Whittaker, 1999) stands in contrast to the vision of easy, seamless connection produced by Barry for the prospective client presented earlier. Barry presented the ClientInfo database as a 'solution' to the issue of knowledge sharing in distributed teams:

...we have a database that you can access from anywhere, where you can upload information, to keep that knowledge sharing going. 
A second key point is that the ideal of seamless interconnectivity remained elusive. The two solutions to their problems put forward - updating ClientInfo while at an office (turns 3-4) or asking a colleague to email a copy (turns 12-13) - fail to meet their standard of supporting 'working anywhere'. Kevin (turn 2) admits he travels to a company office to update the database. Eric makes an ironic comment about how he was free to 'work anywhere' until the database required him to be in a company office (turn 11). Terry also concedes that it is a "pain” (turn 4). These attempts at 'muddling through' and 'getting by' reveal a different side to the seamless vision of flexible work promoted by the consultants. Forms of 'rigidity' appeared to be constructed alongside their 'flexibility' (Tienari and Tainio, 1999).

This extract of data could be seen as an anomaly; a one-off event that was not representative of their working lives. Yet given that the same issue was ongoing months later, coupled with the numerous other technological 'malfunctions' that plagued their working lives - technologies that become even more important for dispersed flexible workers - suggests otherwise. For instance, in the audioconference two weeks later the researcher heard the consultants describe endless attempts to correct this same problem detailed above, including futile calls to the IT helpdesk. The consultants resorted to bringing their laptops to the next team meeting to solve the problem face-to-face. The irony of the story is that ClientInfo, far from enabling dispersed working, became one of the reasons for them to come together to an office.

The point of our analysis is not to highlight the 'teething problems' or malfunctions that are undoubtedly representative of much white-collar, technologically dependent work. Rather, our findings highlight the "concealed practices which are incompatible with fostered impressions” (Goffman, 1959, p.71). 
The front-stage representation delivered by Barry, where technology was heralded as the solution to the 'problem' of dispersed working by enabling the exchange of knowledge from anywhere, anytime, hid and deleted the forms of rigidity and disconnection we observed back-stage. This enabled flexible working to be presented as both desirable and easily achievable, helping the consultants to sell their services and, in so doing, further the interests of their employers. This theme also appeared in another back-stage performance we observed.

\section{Dispersed Teamwork: Hidden Voices}

The researcher had spent the day 'shadowing' Carole and Duncan, both relatively junior consultants, as they worked at hot-desk facilities. As they packed up their laptops, the researcher sparked up a discussion about how the two consultants felt about being flexible workers. The reader is invited to compare Carole and Duncan's story below with the vision of seamless and synergistic teamwork presented by Barry in his front-stage performance to clients (see above).

Researcher: So, how do you guys find the whole working from home thing?

Carol: Well, to be honest with you, it can get a bit lonely at times. And I'm glad you asked because this could be something you could feed back from your research. Because the job I do is different from everyone else in the team, it's more office based, less time seeing clients, so it can get a bit lonely. Like the other week when I mentioned at the team meeting about social isolation, like we could have a T/T club or something, where everyone goes to the same office on a Tuesday and Thursday, when you know there's gonna be someone to 
talk to, and I just got shot down in flames. I was just trying to be proactive, not just talk about it but do something about it.

Duncan: It's true you know, they all talk about meeting regularly to avoid social isolation, but they don't follow through. It pisses me off a bit actually - they just don't practice what they preach.

Carol: $\quad$ The team meetings are supposed to be every month, but they always get cancelled. And when we do meet up, there's too much to cram in, you can't get a word in edgeways. And everyone 'clams up' because they don't know each other, we're all practically strangers. They're all lovely people of course, but these should be my team-mates, people I can bounce ideas with, have a laugh with.

Duncan: $\quad$ I agree. It's not the same as being in an office, where you can just wander up and have a chat. I actually miss being in an office. In fact, I really miss the beers after work on a Friday. That's what we should have, a nonwork meeting in a pub, but I suppose everyone is so far away and they've got kids too. But especially when you're new to a team and just developing, then it's really important. I mean, I could be dead for two weeks and my boss would never know!

This narrative stands in contrast to the story told by Barry to the prospective clients. Barry claimed that teamwork was not adversely affected by teleworking, if the client followed their 'best practice' example of using technology and meeting regularly:

...face-to-face contact [is] ... more important than ever, so we make sure we meet up every month for a team meeting. 
The back-stage conversation with Carole and Duncan, on the other hand, paints a picture of social isolation (eg. Carole: “...it can get a bit lonely”, Duncan: "I really miss the beers after work on a Friday"), a lack of face-to-face interaction (eg. Duncan: "they all talk about meeting regularly to avoid social isolation, but they don't follow through", Carole: "[team meetings] always get cancelled”), and the difficulties of working as a dispersed 'team' (eg. Carole: “these should be my teammates", Duncan: "I actually miss being in an office”).

This resonates with the findings of other studies of home-based flexible working, where respondents have reported feeling socially isolated and 'out of sight, out of mind' from their employers and colleagues (Stanworth and Stanworth, 1991; Fireman, 1998; Mirchandani, 1999; Bertin and Denbigh, 2000). However, our claim is not that this back-stage discussion comprises the 'true' story. Both the front-stage and backstage interactions we observed were constructed with particular audiences and aims in mind. For instance, Carole asked if her comments might be 'fed back' from the research, perhaps to catalyse changes to their working arrangement. The researcher could have therefore acted as a 'sounding board' for Carole and Duncan to 'let off steam' about the 'gripes' of their job. Carole and Duncan tended to avoid reproducing their dissatisfaction and disillusionment in front of colleagues or clients. Moreover, whilst the 'deletion' of these stories from the front-stage performance could be seen as form of strategic manipulation (Goffman, 1959, p.29), we see it as simply part of the job of being a consultant. In fact, both Carole and Duncan were relatively successful in promoting flexible working and even described the enjoyment they derived from their jobs. For example, Duncan described the satisfaction he derived from 'converting' clients in his interview: 
Researcher: So does your job involve seeing clients as well?

Duncan: $\quad$ Oh yes, chasing new business, trying to drum up things. [Pause] I've been kind of successful at that and it's been something I've really enjoyed ... It's about changing perception and saying [to clients] 'You've got the hot buttons there, so why don't you develop a flexible working strategy? Get people talking about it. Changing their minds. I think I've maybe converted maybe one or two, I've had maybe 10 opportunities.

It appears that Duncan managed to perform an enthusiastic commitment to his job of promoting flexible work whilst also being critical of his current flexible working arrangement. The skill of being a consultant, it seems, lies in producing stories that were appropriate to the context - however contradictory these stories may be. More importantly, it was this ability to sustain this ambiguous and ambivalent position between practicing and preaching flexible working that seemed to enable the reproduction of utopian representations of flexibility - representations designed to benefit the firm and expand the market for its products.

\section{Discussion and Conclusion}

This study has examined a group of management consultants that played an important role in shaping the debate on flexibility. The study exposes the 'gap' between the visions of seamless knowledge sharing, synergistic virtual teamwork and strong social networks produced by the consultants for the benefit of clients and the tales of isolation, dis-connection, disaffection and cynicism we observed when clients were not present. These findings are relevant to other types of flexibility, not only technology-enabled flexibility, insofar as other visions of flexibility (such as flexible 
working hours, contracting out, job rotation, multi-tasking, temporary contracts, flexible pay systems etc.) are promoted by actors with a vested interest or agenda in their advancement (such as the State, trade unions, environmental interest groups etc).

The process whereby certain practices were made 'invisible' and certain voices kept 'hidden' is, we suggest, a political and power-laden process insofar as it enables the reproduction of idealistic visions of technology-enabled flexibility - visions aimed at expanding the market for Alpha's telecommunications products and services. This form of 'structured invisibility' may in fact be common amongst 'knowledge professionals'. For instance, the findings of this study resonate with how scientists hide the 'trial and error' involved in scientific work in the 'sanitised' and 'rationalised' accounts of published articles (Gilbert and Mulkay, 1984; Latour and Woolgar, 1986). Further, as Goffman argues, front-stage impressions are often carefully crafted to offer signs that imply knowledge and competence: "many service occupations offer their clients a performance that is illuminated with dramatic expressions of cleanliness, modernity, competence, and integrity” (Goffman, 1959: 36), such as the consultant's choice of pin-stripe suit for example (Jackall, 1988). The events described in this paper could therefore be seen as a political form of representational practice that is commonly used to sustain the impression of being a 'knowledgeable expert'. Our findings suggest that the consultants were not always ‘evangelists' or even just 'messengers' of the corporate language they were expected to reproduce (cf McCabe, 2000). They were themselves critical of, and cynical about, the utopian visions they sell to clients. However, we found that the utopian visions were reproduced in spite of the cynicism and criticism they also generated, leaving clients with a distinctly one-sided view of the realities of telework. 
The representational politics we describe do not necessarily indicate a cynical and manipulative 'industry of deceit'. While consultants have been described as ‘witchdoctors' (Clark and Salaman, 1996a) and 'whores in pin strip suits’ (Jackall, 1988), we think it is too simplistic to see the consultants as 'con-men' who deliberately lured clients into false 'utopian’ visions of flexibility. The consultants faced losing their jobs if they failed to 'convert' enough clients, making it understandable that the back-stage stories of technological failure and social isolation were made 'invisible' to clients. Clients were also more likely to purchase advice from consultants who presented themselves as 'experts' and 'exemplars' of flexible work as opposed to struggling to manage the technological, social and personal changes it involved.

The findings of this study highlight the politics involved in the practices of representing flexibility in certain ways. Ways of representing a particular phenomenon - in this case flexible working - are not simply 'rhetorical' in any superficial or ornamental sense (Burke, 1969, p.60), but rather have material outcomes for those who encounter them. For example, representing domestic violence as a 'domestic squabble' can act to 'naturalise' and 'individualise' the phenomenon, making police intervention less likely and in turn reducing the chances of justice for its victims (Rapping, 2003). In a similar manner, ways of representing certain groups according to race, gender or sexuality, for instance, can act to reproduce patterns of prejudice and discrimination (Wetherell, Stiven \& Potter, 1987; Potter \& Wetherell, 1992; Pickering, 1995).

In our study, representing technology-enabled flexible working as a neutral source of organizational and individual flexibility helped to obscure the 'dark side' of flexible working that was hidden behind the front-stage representations given by the 
consultants. These utopian visions were designed to further the market for Alpha's products and services, not to help workers to balance the demands of work and home (eg. Tietze \& Musson, 2005). For example, the consultants in our study represented technology as liberating workers from the constraints of time and place and enabling workers to achieve new forms of work-life balance by working from home. However, technology can be used to construct very different flexible working practices. Homebased call centre operatives, for example, may have a radically different experience, particularly in cases where they are enslaved by technologies designed to measure call times and monitor toilet breaks (Bain \& Taylor, 2000), leading to new forms of worklife imbalance (Baines \& Gelder, 2003; Hyman et al, 2003).

The consultants in our study did not have a monopoly on the meaning of flexibility. FlexiTeam were only one of many actors seeking to define what flexible working 'is' and can 'do', including unions, managers, government, workers and their families, amongst others. Notwithstanding, consultants such as FlexiTeam comprise a powerful and influential voice in shaping the terms of the debate and, as such, can lead to significant material changes at the level of economy, labour market, organization and individual. For example, in cases where FlexiTeam's utopian vision leads to the implementation of home-based working or virtual teams, workers and their families can find themselves struggling to manage the changes involved when 'work’ comes ‘home’ (Baines \& Gelder, 2003; Hyman, Scholarios \& Baldry, 2005; Tietze \& Musson, 2005; Bone, 2006; Peper, Den Dulk \& Van Doorne-Huiskes, 2005; Taskin \& Edwards, 2007), or the stress and overload when technologies that can be used 'anywhere, anytime' lead to expectations of working 'everywhere, all the time' (Jackson, 1999; Baruch, 2000; Mann \& Holdsworth, 2003). For example, Smithson et al. (2004: 115) argued that the promotion of flexible working among chartered 
accountants meant, in practice, that women "did so to combine working with caring commitments, in ways that damaged their career prospects.”

For practitioners, our study shows that seemingly 'neutral' representations of flexibility require critical interrogation. Does purchasing a laptop or internet connection lead to automatic benefits such as work-life balance, a reduction in commuter carbon emissions, increased community involvement and the regeneration of the countryside in the form of tele-cottages? These are all claims made by the consultants in this study. We invite both scholars and practitioners to critically analyse claims about flexibility and ask what power relations might be reproduced in the process. As Kalleberg (2001) rightly asked, are benefits from flexibility shared with employees, in a 'win-win' scenario? Or does the outcome depend on whose interests are served by flexible working arrangements? Hyman et al. (2005: 719) found that "employers show little enthusiasm for employee flexibility unless it is on terms from which they expect to derive benefit”. Exposing the interests behind representations of flexibility, we suggest, is critical for creating space for imagining different forms of technology-enabled flexibility. 


\section{Notes}

${ }^{1}$ While the terms 'teleworking' and 'virtual working' had also been used by the consultants in the past, the term 'flexible working' was preferred by the consultants at the time of the study. We therefore use this term in the paper for reasons of consistency.

2 The data extracts in this paper based upon ethnographic field-notes are constructed following Watson’s (2000) 'ethnographic fiction science’. They are based upon reallife encounters in the field but use creative licence in lieu of the accuracy of taperecorded conversation. One advantage of this approach is the ability to present themes and issues that are readily discussed in informal settings and less readily discussed when tape-recorders are present.

\section{Acknowledgements}

The author would like to thank the Economic and Social Research Council for supporting the research upon which this article is based; grant numbers 00429934467 and 026270239.

\section{References}

Allan, C., P. Brosnan and P. Walsh (1998), 'Non-standard working-time arrangements in Australia and NZ', International Journal of Manpower, 19, 4, 234-250.

Atkinson, J. (1984), 'Manpower strategies for flexible organisations', Personnel Management, 16, 8, 28-31.

Bain, P. and P. Taylor (2000), 'Entrapped by the 'electronic panopticon'? Worker resistance in the call centre', New Technology, Work and Employment, 15, 1, 218.

Baines, S. (1999), 'Servicing the media: freelancing, teleworking and 'enterprising' careers', New Technology, Work and Employment, 14, 1, 18-31.

Baines, S. and U. Gelder (2003), 'What is family friendly about the workplace in the home? The case of self-employed parents and their children', New Technology, Work and Employment, 18, 3, 223-234.

Baruch, Y. (2000), 'Teleworking: benefits and pitfalls as perceived by professionals and managers', New Technology, Work and Employment, 15, 1, 34-49.

Bertin, I. and A. Denbigh (2000), The Teleworking Handbook. 3rd edition (Kenilworth: Alphattage Association). 
Bolin M and A. Härenstam (2008), 'An empirical study of bureaucratic and postbureaucratic characteristics in 90 workplaces', Economic and Industrial Democracy, 29, 4, 541-564.

Bone, J. (2006), 'The longest day': 'flexible' contracts, performance-related pay and risk shifting in the UK direct selling sector', Work, Employment \& Society, 20, 1, 109-127.

Bryant, S. (2000), 'At home on the electronic frontier: work, gender and the information highway', New Technology, Work and Employment, 15, 1, 19-33.

Bryman, A. (1989), Research Methods and Organization Studies. (London, Routledge) [2000 reprint].

Bryman, A. and R. Burgess (1994), 'Reflections on Qualitative Data Analysis' in Bryman, A. and R. Burgess (eds) Analysing Qualitative Data. 216-226, (London: Routledge).

Burke, K. (1969), A Rhetoric of Motives. (Berkeley: University of California Press) [1 $1^{\text {st }}$ edition 1950]

Capelli, P. and D. Neumark (2004), 'External Churning and Internal Flexibility: evidence on the Functional Flexibility and Core-Periphery Hypotheses', Industrial Relations, 43, 1, 148-182.

Chirumbolo, A. and J. Hellgren (2003), 'Individual and Organizational Consequences of Job Insecurity: A European Study', Economic and Industrial Democracy, 24, 217-240.

Clark, T. (1995), Managing consultants: Consultancy as the management of impressions. (Buckingham: Open University Press).

Clark, T. and I. Mangham (2004), 'From dramaturgy to theatre as technology: The case of corporate theatre', Journal of Management Studies, 41, 2, 37-59.

Clarke, J. and J. Newman (1997), The Managerial State. (London: Sage).

Clark, T. and J. Salaman (1998), 'Telling tales: management gurus' narratives and the construction of managerial identity', Journal of Management Studies, 35, 2, 137161.

Clark, T. and G. Salaman (1996), 'Management gurus as organisational witchdoctors', Organization, 3, 1, 85-107.

Dawson, P. and J. Webb (1989), 'New production arrangements: the totally flexible cage?’, Work, Employment and Society, 3, 2, 221-38.

Dimitrova, D. (2003) 'Controlling teleworkers: supervision and flexibility revisited', New Technology, Work and Employment 18, 3, 181-195.

Fireman, S. 1998. Evolution of the Telecommuting Withdrawal Model: a US perspective. In: Jackson, P.J. and van der Wielen, J.M. (Eds.), Teleworking: International Perspectives. From telecommuting to the virtual organization. (London: Routledge). 281-291

Furåker, B., K. Håkansson and J. Karlsson (eds) (2007) Flexibility and Stability in Working Life. (Basingstoke: Palgrave Macmillan).

Gardner, W. and B. Avolio (1998), 'The charismatic relationship: A dramaturgical perspective', Academy of Management Review, 23, 32-58. 
Geertz, C. (1988), Works and Lives: The Anthropologist as Author. (Stanford: Stanford University Press).

Gilbert, N. and M. Mulkay (1984), Opening Pandora's Box: A Sociological Analysis of Scientists' Discourse. (Cambridge: Cambridge University Press).

Goffman, E. (1959), The Presentation of Self in Everyday Life. (Harmondsworth: Penguin Books) [1974 reprint].

Goffman, E. (1972), Interaction Ritual. (London: Allen Lane).

Goffman E. (1974), Frame analysis. (New York: Harper).

Hammersley, M. and P. Atkinson (1995), Ethnography: Principles in Practice. 2nd edition (London: Routledge).

Hardill, I. \& Green, A. (2003), Remote working-altering the spatial contours of work and home in the new economy, New Technology, Work and Employment, 18, 3, 212-222

Heery, E. (1997), 'Performance-related pay and trade union de-recognition', Employee Relations, 19, 3, 208-221.

Heiler, K. (1998), 'The 'petty pilfering' of minutes or what has happened to the length of the working day in Australia?', International Journal of Manpower, 19, 4, 266280.

Hodgson, D. (2004), 'Project Work: The Legacy of Bureaucratic Control in the PostBureaucratic Organization’, Organization, 11, 1, 81-100.

Hollway, W. and T. Jefferson (2000), Doing Qualitative Research Differently. (London: Sage).

Hughes, C. (1994) 'From Field Notes to Dissertation: Analysing the Stepfamily' in Bryman, A. and R. Burgess (eds.) (1994), Analysing Qualitative Data. 35-46, (London: Routledge).

Huws, U. (1996), Teleworking and Gender. (Brighton: Institute for Employment Studies).

Hyman, J., D. Scholarios and C. Baldry (2005), 'Getting on or getting by? Employee flexibility and coping strategies for home and work', Work Employment and Society, 19, 4, 705-725.

Hyman, J., C. Baldry, D. Scholarios and D. Bunzel (2003), 'Work-life imbalance in the new service sector economy', British Journal of Industrial Relations, 41, 2, 215-239.

Jackall, R. (1988), Moral Mazes: The World of Corporate Managers. (Oxford: Oxford University Press).

Jackson, P. (ed) (1999), Virtual Working: Social and Organisational Dynamics. (London: Routledge).

Kalleberg, L. (2001), 'Organizing Flexibility: The Flexible Firm in a New Century', British Journal of Industrial Relations, 39, 4, 479-504.

Kanter, R.M. (1985), The change masters. (London: Unwin Paperbacks).

Latour, B. and S. Woolgar (1986), Laboratory Life: The Construction of Scientific Facts. (Chichester: Princeton University Press). 
Legge, K. (1995), Human Resource Management: Rhetoric and Realities. (Basingstoke: Pitman).

Mangham, I. and M. Overington (1987), Organizations as Theatre: A Social Psychology of Dramatic Appearances. (Chichester: John Wiley \& Sons).

Mann, S. and L. Holdsworth (2003) 'The psychological impact of teleworking: stress, emotions and health', New Technology, Work and Employment, 18, 3, 196-211.

Maznevski, M. and K. Chudoba (2000), 'Bridging space over time: global virtual team dynamics and effectiveness’, Organization Science, 11, 5, 473-492.

McCabe, D. (2000), 'Factory Innovations and Management Machinations: The Productive and Repressive Relations of Power', Journal of Management Studies, 37, 7, 391-358.

Mirchandani, K. (1999), 'Legitimizing work: telework and the gendered reification of the work-nonwork dichotomy', Canadian Review of Sociology and Anthropology, 36, 1, 87-107.

Mueller, F. (1992), 'Flexible working practices in engine plants: Evidence from the European automobile industry’, Industrial Relations Journal, 23, 3, 191-204.

Mueller, F. (1994), Teams between hierarchy and commitment: change strategies and the 'internal environment', Journal of Management Studies, 31, 383-403.

Nilles, J.M. (1976), The Telecommunication-Transportation Trade-off. (Wiley: New York).

Okely, J. (1994), 'Thinking through Fieldwork', in Bryman, A. and R. Burgess (eds.) (1994) Analysing Qualitative Data. 18-34, (London: Routledge).

Osterman, P. (1988), Employment Futures. (New York: Oxford University Press).

Peper, B., L. Den Dulk and A. Van Doorne-Huiskes (eds) (2005), Flexible Working and Organizational Change. (Aldershot: Edward Elgar).

Peters, T. (1992), Liberation Management. (Basingstoke: Macmillan).

Pickering, M. (1995), 'The politics and psychology of stereotyping', Media Culture \& Society, 17, 4, 691-700.

Platman, K. (2004), 'Portfolio careers' and the search for flexibility in later life', Work, Employment \& Society, 18, 3, 573-599.

Pollert, A. (ed) (1991), Farewell to Flexibility. (Oxford: Blackwell Business).

Poster, W.R. (2007), 'Who's On the Line? Indian Call Center Agents Pose as Americans for U.S.-Outsourced Firms’, Industrial Relations, 46, 2, 271-304.

Potter, J. and Wetherell, M. (1992), Mapping the Language of Racism. (Hemel Hempstead: Harvester Wheatsheaf).

Pyöriä, P. (2003), 'Knowledge work in distributed environments: Issues and illusions', New Technology, Work and Employment, 18, 3, 166-180.

Rapping, E. (2003), Law and Justice as Seen on TV. (New York: NYU Press).

Rosenfeld, P., R. Giacalone and C. Riordan (1995), Impression Management in Organizations. (London: Routledge). 
Schwartz, H., Nardi, B. and Whittaker, S. (1999), 'The hidden work in virtual work' Paper presented at International Conference of Critical Management Studies, July 1999, Manchester, UK.

Sels, L. and R. Huys (1999), 'Towards a flexible future? The nature of organizational response in the. clothing industry', New Technology, Work and Employment, 14, 2, 113-128.

Sennett, R. (2006), The culture of the new capitalism. (New Haven: Yale University Press).

Sewell, G. (1998), 'The Discipline of Teams: The Control of Team-based Industrial Work through Electronic Surveillance', Administrative Science Quarterly, 43, 397-428.

Silverman, D. (1993), Interpreting Qualitative Data. (London: Sage).

Smithson, J., S. Lewis, C. Cooper and J. Dyer (2004), 'Flexible working and the gender pay gap in the accountancy profession', Work, Employment and Society, 18, 1, 115-135.

Stanworth, C. and J. Stanworth (1991), Telework: The Human Resource Management Implications. (London: Institute of Personnel Management).

Star, S. L. and A. Strauss (1999), 'Layers of Silence, Arenas of Voice: The Ecology of Visible and Invisible Work', Computer Supported Cooperative Work, 8, 9-30.

Sullivan, C. (2003), 'What's in a name? Definitions and conceptualisations of teleworking and homeworking', New Technology, Work and Employment, 18, 3, 158-165.

Taskin, L. and P. Edwards (2007), 'The possibilities and limits of telework in a bureaucratic environment: Lessons from the public sector', New Technology, Work and Employment, 22, 3, 195-207.

Thompson, P and C. Warhurst (eds) (1998), Workplaces of the Future. (London, Macmillan).

Tienari, J. and R. Tainio (1999), 'The Myth of Flexibility in Organizational Change', Scandinavian Journal of Management, 15, 4, 351-384.

Tietze, S. and G. Musson (2005), 'Recasting the Home-Work Relationship: A Case of Mutual Adjustment?’, Organization Studies, 26, 9, 1331-1352.

Vallas, S. (1999), 'Rethinking Post-Fordism: The Meaning of Workplace Flexibility', Sociological Theory, 17, 1, 68-101.

Van Maanen, J. (1988), Tales of the Field: On Writing Ethnography. (Chicago: University of Chicago Press).

Voudouris, I. (2007), 'The co-evolution of functional and numerical flexibility: do technology and networking matter?', New Technology, Work and Employment, 22, 3, 224-245.

Watson, T. (2000), 'Ethnographic Fiction Science: Making Sense of Managerial Work and Organisational Research Processes with Caroline and Terry', Organization, 7, 3, 31-38. 
Wetherell, M., H. Stiven and J. Potter (1987), 'Unequal Egalitarianism: A Preliminary Study of Discourses Concerning Gender and Employment Opportunities', British Journal of Social Psychology, 26, 59-71.

Wilks, L. and J. Billsberry (2007), 'Should we do away with teleworking? An examination of whether teleworking can be defined in the new world of work', New Technology, Work and Employment, 22, 2, 168-177.

Woolgar, S. (ed.) (2002), Virtual society? Technology, cyberbole, reality. (Oxford: Oxford University Press). 